\title{
The Potent Cytotoxic and Oxidative Effects of $\beta-2$ Selective ICl- 118,551 on Breast Adenocarcinoma Cell Lines with Different Aggressiveness
}

\author{
Berna Kavakcioglu Yardimci \\ Pamukkale University, Faculty of Arts and Sciences, Department of Chemistry, Denizli, Turkey \\ Correspondence Author: Berna Kavakcioglu Yardimci \\ E-mail: byardimci@pau.edu.tr
}

Received: 29.07 .2020

Accepted: 11.02 .2021

\begin{abstract}
Objective: Beta-blockers are a group of drugs used in the treatment of cardiovascular diseases. On the other hand, the potential anticancer effects of these drugs have become increasingly important in recent two decades. In this paper, the effects of beta- 1 selective esmolol, beta- 2 selective ICl-118,551 and non-selective nadolol on breast cancer cell lines with different aggressiveness were investigated for the first time.

Methods: A standard spectrophotometricMTT assay was used to determine cell viability. Catalase activities and malondialdehyde levels were measured spectrophotometrically based on the reduction of absorbance resulted from hydrogen peroxide decomposition and the formation of thiobarbituric acid - malondialdehyde product, respectively.

Results: It was found that beta-2 selective ICI-118,551 was the most effective one among investigated blockers against MCF-7 and

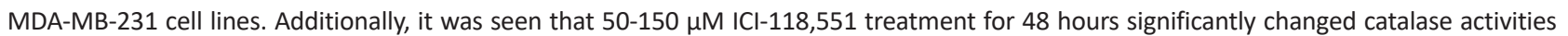
and malondialdehyde levels in both breast cancer cell lines in favour of radical production.

Conclusion: The obtained results showed that beta-2 adrenergic receptor specific antagonism plays a significant role in beta-blocker induced breast cancer cell death. The outstanding suppression in catalase activities and concomitant increase in radical levels appear to contribute to potent cytotoxic effect of ICl-118,551 on breast adenocarcinoma. Consequently, it can be clearly interpreted that ICI-118,551 may be a valuable option in the treatment of breast cancer.
\end{abstract}

Keywords: Esmolol, ICI-118,551, nadolol, breast adenocarcinoma.

\section{INTRODUCTION}

Adrenergic receptors, also called as adrenoceptors, are the cell surface components that play a central role in the sympathetic nervous system and form a class of $G$ protein-bound receptors.They are classified as alpha ( $\alpha-1$ and $\alpha-2)$ and beta ( $\beta-1$ and $\beta-2$ ) based on the interactions with their agonists and antagonists.Adrenergic receptors are the targets of medications such as $\alpha-$ and $\beta$-blockers as well as catecholamines including norepinephrine and epinephrine. The classification of these $\alpha$ - and $\beta$-blockers is done based on the type of receptor affected and these drugs are used in the treatment of conditions such as high blood pressure, migraine, irregular heart rhythm, heart failure, heart attack and chest pain (1).In addition to the routine use of adrenergic receptor blockers in the treatment of the specified ailments, their effects on proliferations of various healthy and cancerous cell/tissue types have been also investigated, especially in studies conducted over the last 20 years. It should be noted that these researches are very valuable in terms of focusing both the side effects and possible off-label usages of the so-called medications with known pharmacology.For instance, it was found that while non-selective $\beta$-blockers carvedilol and propranolol, and $\beta-1$ selective atenolol suppressed endoplasmic reticulum stress, oxidative stress and cell death in human coronary artery endothelial and liver cancer cells (2), another $\beta$-1 selective blocker nebivolol inhibited cell proliferation and induced death in human coronary smooth muscle and endothelial cells (3).On the contrary, Uzar and his friends stated that the same blocker protected rat brain from ischemia-induced damage by preventing oxidative stress and cell death(4). The suppression in myocardial cell death was shown for $\beta$-1 selective blocker metoprolol (5-7).In a study conducted by Smith and Smith, propranolol and $\beta-2$ specific blocker ICl-118,551 were shown to induce death in peripheral lung capillary endothelial cells (8). It was found that longevity of patients with ovarian cancer who take atenolol, propranolol, metoprolol, non-selectivelabetolol and carvedilolblockers 
significantly increased compared to patients who did not use (9).In a similar study conducted by Powe et al., it was found that metastasis formation decreased in patients who started $\beta$-blocker treatment before breast cancer diagnosis (10). It was stated in another observationally-based study that while atenolol had no effect, propranolol significantly decreased the mortality rates of breast cancer patients (11).It was also shown for propranolol that this beta-blocker inhibited proliferation and induced significant death in endothelial cells from hemangioma (12-17). Besides hemangioma endothelial cells, propranolol was found to induce cell death in several cancer types including pancreatic and stomach carcinomas, neuroblastoma, and melanoma (18-21). From thisliterature view, it is clearly seen that adrenergic receptor blockers have reverse effects on cell viability depend on the type of affected cell/tissue. In this study, the effects of $\beta-1$ selective esmolol, $\beta-2$ selective ICl-118,551 and non-selective nadolol on breast cancer cell proliferation were examined for the first time. For this aim, two breast cancer cell lines having different aggressiveness were used. Our results showed that all three drugs, but especially $\beta-2$ selective $\mathrm{ICI}-118,551$, have promising activities on breast adenocarcinoma. In addition, it was found that the most effective beta-blocker ICI-118,551 suppressed antioxidant system and caused the formation of oxidative stress, which were determined by catalase activities and malondialdehyde (MDA) levels, respectively.

\section{METHODS}

\subsection{Materials}

All chemicals used were of analytical grade or higher where appropriate and obtained from Sigma-Aldrich, Inc. (St. Louis, MO, USA) unless otherwise stated.

\subsection{Cell Culture}

The human breast adenocarcinoma cell lines, MCF-7 and MDA-MB-231, were obtained from American Type Culture Collection (ATCC, USA). Both cell lines were cultured with high-glucose Dulbecco's modified Eagle's medium (DMEM) supplemented with $100 \mathrm{IU} / \mathrm{mL}$ penicillin, 100 $\mu \mathrm{g} /$ mLstreptomycin and $20 \%$ fetal bovine serum (FBS) in a humidified atmosphere of $95 \%$ air with $5 \% \mathrm{CO}_{2}$ at $37^{\circ} \mathrm{C}$.

\subsection{Determination of Cell Viability}

The effects of esmolol, ICl-118,551 and nadolol on the viability of MCF-7 and MDA-MB-231 cell lines were investigated through MTT assay which based on the reduction of the tetrazolium salt (3-(4,5-Dimethyl-2-thiazolyl)-2,5-diphenyl$2 \mathrm{H}$-tetrazolium bromide) to its insoluble formazan as a result of metabolic activity (22). In the assay, briefly, breast cancer cell lines were seeded into 96-well plates at a density of $1 \times 10^{4}$ per $100 \mu$ Lwell and allowed to attach for $24 \mathrm{~h}$ before drug treatment. Then, the cells were exposed to various concentrations of $\beta$-blockers $(5-250 \mu \mathrm{M})$ for
24 and $48 \mathrm{~h}$. After treatment period, $25 \mu \mathrm{L}$ MTT solution ( $5 \mathrm{mg} / \mathrm{mL}$ hosphate-buffered saline, PBS) was added and the plates were located in an incubator with $5 \% \mathrm{CO}_{2}$ at 37 ${ }^{\circ} \mathrm{C}$. After $4 \mathrm{~h}$ incubation time, insoluble formazan crystals were dissolved in dimethyl sulfoxide (DMSO) and then cell growth was assessed by measuring the absorbance at 570 $\mathrm{nm}$. Cell viability was expressed as percentage survival, with $100 \%$ survival taken as that observed in related control cells. Because DMSO was used as the drug solvent, control cells were treated with maximum $0.1 \%$ or lower concentrations of DMSO. The solvent in the used concentration range was nontoxic and did not influence the viabilities of both cell lines.

\subsection{Crude Extracts Preparation For Biochemical Analysis}

Commercial RIPA Buffer (Sigma, R0278, USA) was used for the cell lysis procedure. Briefly, growth medium was removed by aspiration and cells were washed two times with Dulbecco's phosphate-buffered saline (DPBS) to remove residual medium. After final washing step, an appropriate volume of RIPA Buffer ( $1 \mathrm{~mL}$ for $0.5-5 \times 10^{7}$ cells) was added and cells were incubated on ice for five $\mathrm{min}$. Then, the plates were scraped and the lysates were clarified by centrifugation at $12,000 \mathrm{rpm}$ for $10 \mathrm{~min}$ at $4{ }^{\circ} \mathrm{C}$. Supernatants were carefully transferred into clean tubes and stored at $-70^{\circ} \mathrm{C}$ for future use.

\subsection{Biochemical Analysis}

\subsubsection{Catalase activity}

Catalase activity was determined according to the Aebi method (23). The method is based on the reduction of absorbance at $240 \mathrm{~nm}$ resulted from hydrogen peroxide $\left(\mathrm{H}_{2} \mathrm{O}_{2}\right)$ decomposition by catalase at $25^{\circ} \mathrm{C} .10 .5 \mathrm{mM} \mathrm{H}_{2} \mathrm{O}_{2}$ prepared in $50 \mathrm{mM}$ phosphate buffer $(\mathrm{pH}$ 7.0) was used in the assay. $1 \mathrm{U}$ enzyme activity is defined as the amount of enzyme required to decompose $1 \mu \mathrm{mol} \mathrm{H}_{2} \mathrm{O}_{2}$ under standard conditions. Enzyme activity was calculated using the molar extinction coefficient of $\mathrm{H}_{2} \mathrm{O}_{2}\left(39.4 \mathrm{~L} \mathrm{mmol}^{-1} \mathrm{~cm}^{-1}\right)$.

\subsubsection{Membrane lipid peroxidation levels}

MDAis a stable by-product of membrane lipid peroxidation. To assess the membrane lipid peroxidation levels, the formation of MDA was measured by using the thiobarbituric acid (TBA) reaction (24). Briefly, $500 \mu \mathrm{L}$ cell lysate was incubated with $500 \mu \mathrm{L} 10 \%$ trichloroacetic acid (TCA) for $15 \mathrm{~min}$ at $90{ }^{\circ} \mathrm{C}$. After 10 min centrifugation, $500 \mu \mathrm{L}$ supernatant was mixed with $500 \mu \mathrm{LTBA}$ and again incubated for $15 \mathrm{~min}$ at $90^{\circ} \mathrm{C}$. The absorbance of MDA-TBA product in $532 \mathrm{~nm}$ was recorded against blank. Lipid peroxidation levels were calculated using the molar extinction coefficient of MDA $\left(1.56 \times 10^{5} \mathrm{~mol} \mathrm{~L}^{-1} \mathrm{~cm}^{-}\right.$ $\left.{ }^{1}\right)$. 


\subsubsection{Total protein levels}

Bradford method was used for the measurement of the total protein concentration in the cell lysates (25). Briefly, $100 \mu \mathrm{L}$ sample was mixed with $900 \mu \mathrm{L}$ Bradford reagent prepared by using Coomassie Brilliant Blue G-250 dye and after 2 min incubation, the absorbance in $595 \mathrm{~nm}$ was recorded against blank.Bovine serum albumin (BSA) was used asa standard.

\subsection{Statistical Analysis}

The data are presented as the mean \pm S.E.M. The differences in variance were analyzed statistically using a one-way analysis of variance (ANOVA) test by Graphpad prism 5.0 statistics software (GraphPad, La Jolla, CA, USA). Tukey's test was used as a post hoc.

\section{RESULTS}

\subsection{The Effects of Beta-Blockers on Breast Adenocarcinoma Cell Viability}

The antiproliferative effects of $5-250 \mu \mathrm{M} \quad \beta-1$ selective esmolol, $\beta-2$ selective ICl-118,551 and non-selective nadolol on breast cancer cell lines were investigated for 24 and $48 \mathrm{~h}$. For this aim, two different cell lines with different aggressiveness, MCF-7 and MDA-MB-231, were used. MCF-7 cell line which has a normal expression of human epidermal growth factor receptor 2 (HER2) is estrogen and progesterone-receptors positive. On the other hand, MDA-MB-231 cells are triple negative and therefore more aggressiveand less chemosensitive to conventional cytotoxic agentsthan the first one (26).We observed that there was no any significant difference between control and5-10 $\mu \mathrm{M}$ esmolol treated groups after $24 \mathrm{~h}$ treatment in MCF-7 cell line.Although 25-250 $\mu \mathrm{M}$ esmolol could significantly inhibit cell viability compared to the control, the cytotoxicitydid not gradually increase with the increasing concentrations of the drug (Figure 1A).This cell line became sensitive to the lowest concentrations of esmolol after an additional $24 \mathrm{~h}$ of treatment. The same pattern for higher concentrations of the drug wasalso recorded but cell viability could not be reduced below 56\% (Figure 1B). It was observed that MDA-MB-231 cell line was more resistant to esmolol (Figure 2). Whilecell viability could not be significantly reduced compared to the control group up to 150 and $250 \mu \mathrm{M}$ of esmolol for 24 and 48 $h$, respectively, it was even insignificantly induced at lower concentrations of the drug. The viability percentage of MDA$\mathrm{MB}-231$ cells treated with the highest concentration of esmolol was determined as $68.40 \pm 11.72$. Unlike esmolol, ICI-118,551 was observed to be highly effective against breast cancer cell proliferation (Figures 3 and 4). As can be seen from Figure 3A,

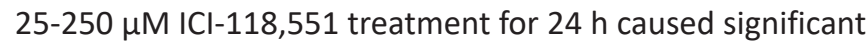
inhibition of MCF-7 cell proliferation compared with the control group and this inhibition was generally correlated with the increasing concentration of the drug. This potent cytotoxic effect of $\mathrm{ICl}-118,551$ was further enhanced by 48 $\mathrm{h}$ treatment and viability decreased up to $5.33 \pm 1.13$ (Figure $3 B)$. More aggressive breast cancer cell line MDA-MB-231 was again found more resistant to this blocker, but especially for highest concentrations and longer treatment period. Nevertheless, it was observed that cell viability significantly reduced below $50 \%$ from $100 \mu \mathrm{M}$ onwards in both 24 and $48 \mathrm{~h}$ treatments. Despite it was observed that nadolol was slightly more effective than esmolol, viability values below $50 \%$ could not be obtained for both cell lines (Figures 5 and $6)$. As is the case with $\beta-1$ selective esmolol and $\beta-2$ selective $\mathrm{ICl}-118,551$, triple negative MDA-MB-231 cell line showed more resistance to non-selective nadolol than MCF-7. Given all these results, it is obvious that $\beta-2$ selective $\mathrm{ICl}-118,551$ is much more effective on breast cancer than other investigated blockers.

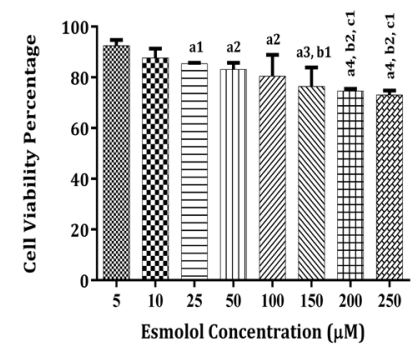

(A)

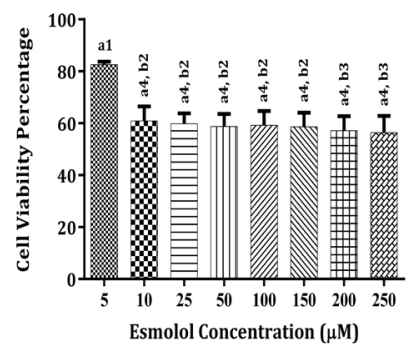

Figure 1. The effects of different concentrations of esmolol on viability percentage of MCF-7 cells for $24 h(A)$ and $48 h$ (B). Data with error bars show the mean \pm S.E.M of three experiments. adenotes significant differences between other studied groups and control group $\left({ }^{a 1} p<0.05 ;{ }^{a 2} p<0.01 ;{ }^{a 3} p<0.001 ;{ }^{a 4} p<0.0001\right), b$ denotes significant differences between other studied groups and $5 \mu \mathrm{M}$ esmolol treated group $\left({ }^{b 1} p<0.05 ;{ }^{b 2} p<0.01 ;{ }^{b 3} p<0.001\right), c$ denotes significant differences between other studied groups and $10 \mu \mathrm{M}$ esmolol treated group $\left({ }^{c 1} p<0.05\right)$ by Tukey's multiple range tests.

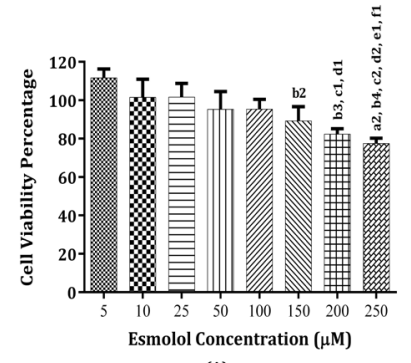

(A)

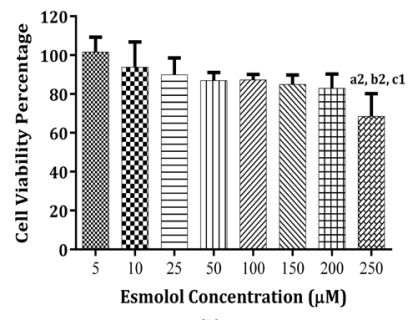

(B)
Figure 2. The effects of different concentrations of esmolol on viability percentage of MDA-MB-231 cells for $24 h(A)$ and $48 h$ (B). Data with error bars show the mean \pm S.E.M of three experiments. adenotes significant differences between other studied groups and control group $\left({ }^{a 2} p<0.01\right), b$ denotes significant differences between other studied groups and $5 \mu \mathrm{M}$ esmolol treated group $\left({ }^{b 2} p<0.01\right.$; $\left.{ }^{b 3} p<0.001 ;{ }^{b 4} p<0.0001\right), c$ denotes significant differences between other studied groups and $10 \mu \mathrm{M}$ esmolol treated group $\left({ }^{c 1} p<0.05\right.$; $\left.{ }^{c 2} p<0.01\right), d$ denotes significant differences between other studied groups and $25 \mu \mathrm{M}$ esmolol treated group $\left({ }^{d 1} p<0.05 ;{ }^{d 2} p<0.01\right)$, $e$ denotes significant differences between other studied groups and $50 \mu \mathrm{M}$ esmolol treated group ( $\left.{ }^{\mathrm{e}} \mathrm{p}<<0.05\right), f$ denotes significant differences between other studied groups and $100 \mu \mathrm{M}$ esmolol treated group $\left({ }^{f 1} p<0.05\right)$ by Tukey's multiple range tests. 


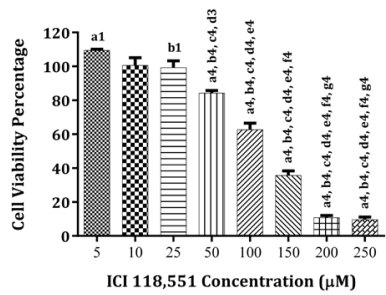

(A)

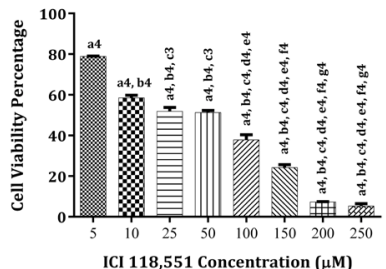

Figure 3. The effects of different concentrations of $I C l-118,551$ on viability percentage of MCF-7 cells for $24 h(A)$ and $48 h(B)$. Data with error bars show the mean \pm S.E.M of three experiments. adenotes significant differences between other studied groups and control group $\left({ }^{a 1} p<0.05 ;{ }^{a 4} p<0.0001\right), b$ denotes significant differences between

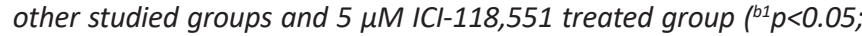
$\left.{ }^{b 4} p<0.0001\right), c$ denotes significant differences between other studied groups and $10 \mu \mathrm{M} \mathrm{ICl}-118,551$ treated group $\left({ }^{c 3} p<0.001 ;{ }^{c 4} p<0.0001\right)$, $d$ denotes significant differences between other studied groups and $25 \mu \mathrm{M}$ ICI-118,551 treated group $\left({ }^{d 3} p<0.001 ;{ }^{d 4} p<0.0001\right)$, e denotes significant differences between other studied groups and $50 \mu \mathrm{M} \mathrm{ICI}$ 118,551 treated group $\left({ }^{e 4} p<0.0001\right), f$ denotes significant differences between other studied groups and $100 \mu \mathrm{M} I \mathrm{Cl}-118,551$ treated group $\left({ }^{54} p<0.0001\right), g$ denotes significant differences between other studied

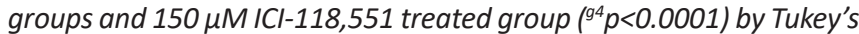
multiple range tests.

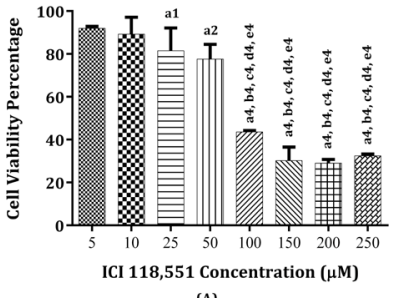

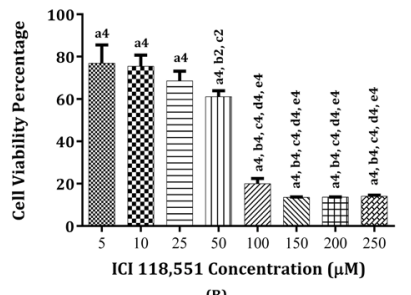

(B)

Figure 4. The effects of different concentrations of ICI-118,551 on viability percentage of MDA-MB-231 cells for $24 h(A)$ and $48 h$ (B). Data with error bars show the mean \pm S.E.M of three experiments. adenotes significant differences between other studied groups and control group $\left({ }^{a 1} p<0.05 ;{ }^{a 2} p<0.01 ;{ }^{a 4} p<0.0001\right)$, $b$ denotes significant differences between other studied groups and $5 \mu \mathrm{M} I \mathrm{Cl}-118,551$ treated group $\left({ }^{b 2} p<0.01 ;{ }^{b 4} p<0.0001\right)$, c denotes significant differences between other studied groups and $10 \mu \mathrm{M} \mathrm{ICl-}$ 118,551 treated group $\left({ }^{c 2} p<0.01 ;{ }^{c 4} p<0.0001\right)$, d denotes significant differences between other studied groups and $25 \mu \mathrm{M}$ ICI-118,551 treated group $\left({ }^{d 4} p<0.0001\right)$, e denotes significant differences between other studied groups and $50 \mu \mathrm{MICl}-118,551$ treated group $\left({ }^{e 4} p<0.0001\right)$ by Tukey's multiple range tests.

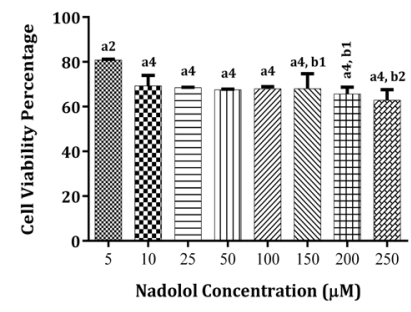

(A)

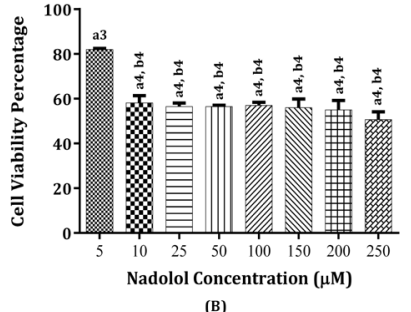

Figure 5. The effects of different concentrations of nadolol on viability percentage of MCF-7 cells for $24 h$ (A) and $48 h$ (B). Data with error bars show the mean \pm S.E.M of three experiments. adenotes significant differences between other studied groups and control group $\left({ }^{a 2} p<0.01 ;{ }^{a 3} p<0.001 ;{ }^{a 4} p<0.0001\right), b$ denotes significant differences between other studied groups and $5 \mu \mathrm{M}$ nadolol treated group ( $\left.{ }^{b 1} p<0.05 ;{ }^{b 2} p<0.01 ;{ }^{b 4} p<0.0001\right)$ by Tukey's multiple range tests.

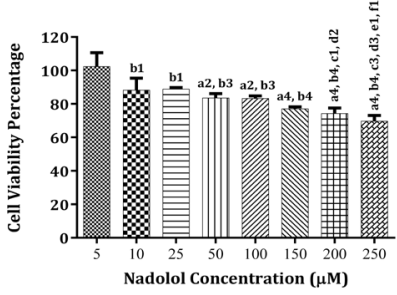

(A)

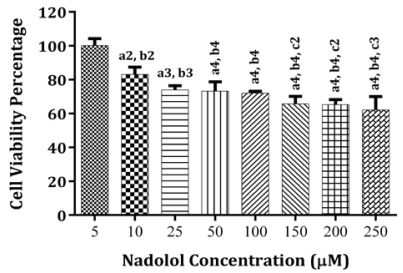

Figure 6. The effects of different concentrations of nadolol on viability percentage of MDA-MB-231 cells for $24 h(A)$ and $48 h(B)$. Data with error bars show the mean \pm S.E.M of three experiments. adenotes significant differences between other studied groups and control group $\left({ }^{a 2} p<0.01 ;{ }^{a 3} p<0.001 ;{ }^{a 4} p<0.0001\right), \quad b$ denotes significant differences between other studied groups and $5 \mu \mathrm{M}$ nadolol treated group ( $\left.{ }^{b 1} p<0.05 ;{ }^{b 2} p<0.01 ;{ }^{b 3} p<0.001 ;{ }^{b 4} p<0.0001\right)$, $c$ denotes significant differences between other studied groups and $10 \mu \mathrm{M}$ nadolol treated group $\left({ }^{11} p<0.05 ;{ }^{c 2} p<0.01 ;{ }^{c 3} p<0.001\right)$, $d$ denotes significant differences between other studied groups and $25 \mu \mathrm{M}$ nadolol treated group $\left({ }^{d 2} p<0.01 ;{ }^{d 3} p<0.001\right)$, e denotes significant differences between other studied groups and $50 \mu \mathrm{M}$ nadolol treated group ( $\left.{ }^{11} p<0.05\right), f$ denotes significant differences between other studied groups and $100 \mu \mathrm{M}$ nadolol treated group $\left({ }^{f 1} p<0.05\right)$ by Tukey's multiple range tests.

\subsection{The Effects of ICl-118,551 on Catalase Activities of Breast Adenocarcinoma}

Catalase is one of the main antioxidant enzymes that catalyzes the dismutation of $\mathrm{H}_{2} \mathrm{O}_{2}$ to molecular oxygen and water. In this study, catalase activities of MCF-7 and MDA-MB-231 cells treated with 50-150 $\mu \mathrm{M}$ ICl-118,551 for $48 \mathrm{~h}$ were determined. It was found for all treatments that catalase activities were significantly decreased compared to related controls $(p<0.0001)$ (Figure 7A-B). These decreases were reached to about 14.7 - and 11.6 -folds at $150 \mu \mathrm{M}$ in MCF-7 and MDA-MB-231 cell lines, respectively.
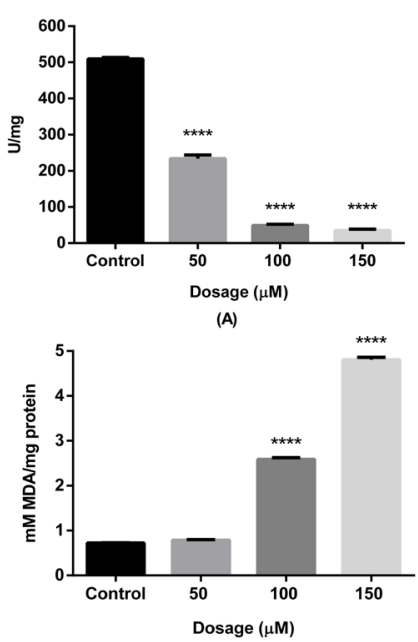

(C)

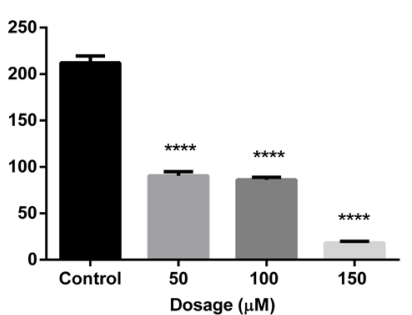

(B)

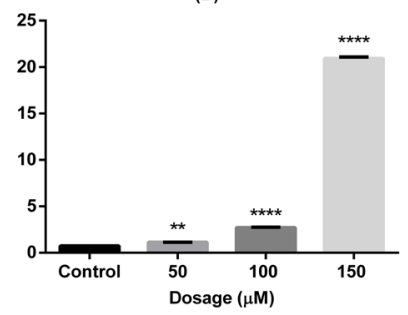

(D)
Figure 7. The effects of different concentrations of ICI-118,551 on catalase activities of MCF-7 (A) andMDA-MB-231 (B) and MDA levels of MCF-7 (C) andMDA-MB-231 (D) cells for $48 \mathrm{~h}$. Data with error bars show the mean \pm S.E.M of three experiments. ${ }^{* *}=p<0.01$; $* * * *=p<0.0001$ denotes significant differences between control and other studied groups by Tukey's multiple range tests. 


\subsection{The Effects of ICI-118,551 on MDALevels of Breast Adenocarcinoma}

In this paper, we also dealt with MDA levels of the samples treated with $50-150 \mu \mathrm{M} \mathrm{ICl}-118,551$ for $48 \mathrm{~h}$. As very well known, MDA level is a reliable indicator of lipid peroxidation resulting from oxidative stress. As can be seen from Figure 7C-D, all treatments caused the significant increases in MDA levels, except $50 \mu \mathrm{M}$ ICl-118,551 treated MCF-7 cells. MDA levels of MCF-7 and MDA-MB-231 cells gradually increased with the increasing concentrations of the blocker and reached to $4.81 \pm 0.06$ and $20.93 \pm 0.18$ by increasing about $6.68-$ and 28.67-folds compared to related controls, respectively. There were moderate negative correlations $\left(r_{\text {MCF- }}=-0.778\right.$; $r_{\text {MDA-MB-231 }}=-0.731$ ) between catalase activities and MDA levels of both cell lines. These findings clearly showed for the first time that the significant suppressions in catalase activitiesand concomitant increases in radical levelscontributed to potent cytotoxic effect of ICl-118,551.

\section{DISCUSSION}

In this paper, the effects of $\beta-1$ selective esmolol, $\beta-2$ selective $\mathrm{ICl}-118,551$ and non-selective nadolol blockers were examined on MCF-7 and MDA-MB-231 cell lines. According to the obtained findings, it was seen that ICl-118,551 rather than esmolol and nadolol has very potent cytotoxic effects on both breast adenocarcinoma lines. As mentioned previously, $\beta$-blockers exert their intracellular effects via interaction with theassociated adrenergic receptors. Hence, the apparent cytotoxicity of $\beta-2$ selective $\mathrm{ICl}-118,551$ on the stated cell lines indicate in a sense that $\beta-2$ adrenergic receptor-specific antagonism plays an important role in $\beta$-blocker induced breast cancer cell death. As a matter of fact, similar results have been reported in some other studies. For instance, Wolter et al. compared the effects of $\beta-1$ and $\beta-2$ specific blockers on neuroblastoma cell line with non-selective blocker propranolol and showed that this non-selective blocker mainly induced death with $\beta$-2specific antagonism (20). It was stated in other recent studies that non-selective propranolol and $\beta-2$ selective $\mathrm{ICl}-118,551$ but not $\beta-1$ selective metoprolol and atenolol were found to be quite effective against human breast and colorectal cancers $(27,28)$. However, there are some data that contradict these results (29). The variations in the expression levels of different $\beta$-adrenergic receptor subtypesin different cell types can be demonstrated as the responsible for this situation. On the other hand, off-target effects of ICl-118,551 on human breast cancer cells should be considered and further investigated due to the inability to reach similar results with non-selective nadolol.

It is known from other studies that $\beta$-blockers have some anti-oxidative effects on healthy/non-cancerous cells and tissues $(30,31)$. On the other hand, according to our literature view, there is no any other research dealing with the effects of $\beta$-blockers on antioxidant system of cancerous cells. Our results indicated that oxidative stress, which wascharacterized by MDA levels, increased as a result of $\beta-2$ selective $\mathrm{ICl}-118,551$ treatment in both cancer cell lines. As it is known, increase in intracellular radical levels, occurrence of oxidative stress and resultant damage in biomolecules is a cascade-like process leading the cell to death. Hence, it is clear that increased oxidative stress status as one of the results of significant decreases in catalase activities contributed to ICl118,551 induced toxicity.

\section{CONCLUSION}

As a conclusion, all these results reveal the potential cytotoxic and oxidative effects of $\mathrm{ICl}-118,551$ on human breast cancer cell lines. The findings obtained on the aggressive MDA-MB-231 model which is resistant to chemotherapy are particularly important. Although high concentrations seem to be required to reach the effective doses in in vitro studies, it is well known that there are significant differences in these doses when compared to in vivo models which require much lower doses of $\beta$-blockers. Therefore, $\beta-2$ selective ICl118,551 may be seen as a potential candidate in the treatment of human breast cancer. Considering the difficulties of the new drug development stages, it is extremely important to find the usability of $\beta$-blockers having no side effects and with known pharmacology in cancer treatment. Finally, we must state that these results should be supported by further in vivo studies.

\section{REFERENCES}

[1] Frishman WH, Saunders E. $\beta$-Adrenergic blockers. J Clin Hypertension 2011;13:649-653.

[2] Haas MJ, Kurban W, Shah H, Onstead-Haas L, Mooradian AD. Beta blockers suppress dextrose-induced endoplasmic reticulum stress, oxidative stress, and apoptosis in human coronary artery endothelial cells. Am J Ther. 2016;23:15241531.

[3] Brehm BR, Wolf SC, Bertsch D, Klaussner M, Wesselborg S, Schüler S, Schulze-Osthoff K. Effects of nebivolol on proliferation and apoptosis of human coronary artery smooth muscle and endothelial cells. Cardiovasc Res. 2001;49:430439.

[4] Uzar E, Acar A, Evliyaoğlu O, Fırat U, Kamasak K, Göçmez C, Alp H, Tüfek A, Taşdemir N, İlhan A. The anti-oxidant and anti-apoptotic effects of nebivolol and zofenopril in a model of cerebral ischemia/reperfusion in rats. Prog Neuro-Psychoph. 2012;36:22-28.

[5] Serpi R, Tolonen AM, Tenhunen O, Pieviläinen O, Kubin AM, Vaskivuo T, Soini Y, Kerkelä R, Leskinen H, Ruskoaho H. Divergent effects of losartan and metoprolol on cardiac remodeling, C-kit+ cells, proliferation and apoptosis in the left ventricle after myocardial infarction. ClinTransl Sci 2009;2:422-430.

[6] Su Q, Li L, Liu YC, Zhou Y, Lu YG, Wen WM. Effect of metoprolol on myocardial apoptosis and caspase- 9 activation after coronary microembolization in rats. Exp Clin Cardiol. 2013; 18:161-165.

[7] Li W, Yan S, Zhao J, Ding X, Zhang S, Wang D, LiuL, Peng W, Li H, Wang D, Liu Z, Liu Y. Metoprolol inhibits cardiac apoptosis and 
fibrosis in a canine model of chronic obstructive sleep apnea. Cell Physiol Biochem. 2015; 36:1131-1141.

[8] Smith SKS, Smith DM. Beta blockade induces apoptosis in cultured capillary endothelial cells. In Vitro Cellular and Developmental Biology-Animal 2002; 38:298-304.

[9] Diaz ES, Karlan BY, Li AJ. Impact of beta blockers on epithelial ovarian cancer survival. Gynecol Oncol. 2012; 127:375-378.

[10] Powe DG, Voss MJ, Zänker KS, Habashy HO, Green AR, Ellis IO, Entschladen F. Beta-blocker drug therapy reduces secondary cancer formation in breast cancer and improves cancer specific survival. Oncotarget 2010; 1:628-638.

[11] Barron TI, Connolly RM, Sharp L, Bennett K, Visvanathan K. Beta blockers and breast cancer mortality: a population-based study. J Clin Oncol. 2011; 29:2635-2644.

[12] Ji Y, Li K, Xiao X, Zheng S, Xu T, Chen S. Effects of propranolol on the proliferation and apoptosis of hemangioma-derived endothelial cells. J Pediatr Surg. 2012; 47:2216-2223.

[13] Wong A, Hardy KL, Kitajewski AM, Shawber CJ, Kitajewski JK, Wu JK. Propranolol accelerates adipogenesis in hemangioma stem cells and causes apoptosis of hemangioma endothelial cells. Plast Reconstr Surg. 2012; 130:1012-1021.

[14] Tu JB, Ma RZ, Dong Q, Jiang F, Hu XY, Li QY, Pattar P, Zhang $\mathrm{H}$. Induction of apoptosis in infantile hemangioma endothelial cells by propranolol. Exp Ther Med. 2013; 6:574-578.

[15] Ma X, Zhao T, Ouyang T, Xin S, Ma Y, Chang M. Propranolol enhanced adipogenesis instead of induction of apoptosis of hemangiomas stem cells. Int J Clin Exp Pathol. 2014; 7:38093817.

[16] Albiñana V, de las Heras KVG, Serrano-Heras G, Segura T, Perona-Moratalla AB, Mota-Pérez $\mathrm{M}$, de Campos JM, Botella LM. Propranolol reduces viability and induces apoptosis in hemangioblastoma cells from von Hippel-Lindau patients. Orphanet J Rare Dis 2015; 10:118-129.

[17] Wnęk A, Andrzejewska E, Kobos J, Taran K, Przewratil P. Molecular and immunohistochemical expression of apoptotic proteins $\mathrm{Bax}, \mathrm{Bcl}-2$ and Caspase 3 in infantile hemangioma tissues as an effect of propranolol treatment. Immunol Lett 2017; 185:27-31.

[18] Zhang D, Ma Q, Shen S, Hu H. Inhibition of pancreatic cancer cell proliferation by propranolol occurs through apoptosis induction: the study of $\beta$-adrenoceptor antagonist's anticancer effect in pancreatic cancer cell. Pancreas 2009; 38:94-100.

[19] Liao X, Che X, Zhao W, Zhang D, Bi T, Wang G. The $\beta$-adrenoceptor antagonist, propranolol, induces human gastric cancer cell apoptosis and cell cycle arrest via inhibiting nuclear factor $\mathrm{KB}$ signaling. Oncol Rep 2010; 24:1669-1676.

[20] Wolter JK, Wolter NE, Blanch A, Partridge T, Cheng L, Morgenstern DA, Podkowa M, Kaplan DR, Irwin MS. Anti-tumor activity of the beta-adrenergic receptor antagonist propranolol in neuroblastoma. Oncotarget 2014; 5:161-172.

[21] Zhou C, Chen $X$, Zeng W, Peng $C$, Huang G, Li XA, Zhengxiao O, Luo Y, Xu X, Xu B, Wang W, He R, Zhang X, Zhang L, Liu J, Knepper TC, He Y, McLeod HL. Propranolol induced G0/G1/S phase arrest and apoptosis in melanoma cells via AKT/MAPK pathway. Oncotarget 2016; 7:68314-68327.

[22] Green LM, Reade JL, Ware CF. Rapid colorimetric assay for cell viability: application to the quantitation of cytotoxic and growth inhibitory lymphokines. J Immunol Methods 1984; 70:257-268.

[23] Aebi H. Catalase. Bergmeyer HU, editor. Methods of Enzymatic Analysis. Cambridge: Academic Press; 1974.p.673-684.

[24] Schmedes A, Hølmer G. A new thiobarbituric acid (TBA) method for determining free malondialdehyde (MDA) and hydroperoxides selectively as a measure of lipid peroxidation. J Am Oil Chem Soc. 1989; 66:813-817.

[25] Bradford MM. A rapid and sensitive method for the quantitation of microgram quantities of protein utilizing the principle of protein-dye binding. Anal Biochem 1976; 72:248-254.

[26] Gründker C, Föst C, Fister S, Nolte N, Günthert AR, Emons G. Gonadotropin-releasing hormone type II antagonist induces apoptosis in MCF-7 and triple-negative MDA-MB-231 human breast cancer cells in vitro and in vivo. Breast Cancer Res 2010; 12:1-9.

[27] Xie WY, He RH, Zhang J, He YJ, Wan Z, Zhou CF, Tang YJ, Li $Z$, Mcleod HL, Liu J. $\beta$-blockers inhibit the viability of breast cancer cells by regulating the ERK/COX-2 signaling pathway and the drug response is affected by ADRB2 single-nucleotide polymorphisms. Oncol Rep 2019; 41:341-350.

[28] Chin CC, Li JM, Lee KF, Huang YC, Wang KC, Lai HC, Cheng CC, Kuo YH, Shi CS. Selective $\beta 2$-AR blockage suppresses colorectal cancer growth through regulation of EGFR-Akt/ ERK1/2 signaling, G1-phase arrest, and apoptosis. J Cellular Physiol 2016; 231:459-472.

[29] Liu X, Wu WK, Yu L, Sung JJ, Srivastava G, Zhang ST, Cho CH. Epinephrine stimulates esophageal squamous-cell carcinoma cell proliferation via $\beta$-adrenoceptor-dependent transactivation of extracellular signal-regulated kinase/ cyclooxygenase-2 pathway. J Cell Biochem 2008; 105:53-60.

[30] MagsinoJr CH, Hamouda W, Bapna V, Ghanim H, Abu-Reish IA, Aljada A, Dandona P. Nadolol inhibits reactive oxygen species generation by leukocytes and linoleic acid oxidation. Am J Cardiol 2000; 86:443-448.

[31] Sharma B, Daga MK, Gambhir DS, Kaushik M. Effect of esmolol, an ultra-short acting beta blocker on oxidant status and antioxidant activity in acute myocardial infarction: Results of a randomized double-blind, controlled, prospective clinical study. Chest 2003; 124:152. 